\title{
Pengembangan Media Bio Pop-Up Book Terintegrasi Science, Environment, Technology, And Society (SETS) Pada Pembelajaran Biologi Materi Daur Biogeokimia
}

\author{
Wahyu Dwi Lestari, Wachidatul Linda Yuhanna, Marheny Lukitasari
}

(C) 2020 JEMS (Jurnal Edukasi Matematika dan Sains)

This is an open access article under the CC-BY-SA license (https://creativecommons.org/licenses/bysa/4.0/) ISSN 2337-9049 (print), ISSN 2502-4671 (online)

\begin{abstract}
Abstrak:
Penelitian pengembangan ini bertujuan mengembangkan media pembelajaran Bio Pop-Up Book terintegrasi SETS pada materi daur Biogeokimia. Hal ini karena pada materi ini diperlukan sebuah media yang nyata sehingga peserta didik dapat membayangkannya. Sehingga dalam proses pembelajarannya peserta didik dapat memunculkan kemampuan intelektual dalam memecahkan suatu masalah. Selaras dengan ilmu sain, lingkungan, teknologi,dan masyarakat. Penelitian ini merupakan penelitian pengembangan. Metode penelitian pengembangan yang digunakan adalah ADDIE yang terdiri dari lima tahapan yang meliputi analisis (Analysis), desain (Design), pengembangan (Development), implementasi (Implementation), dan evaluasi (Evaluation). Data diperoleh dengan validasi ahli materi dan ahli media pembelajaran. Hasil dari validasi ahli materi di peroleh $87 \%$ termasuk kualifikasi sangat baik dengan dan hasil validasi ahli media pembelajaran di peroleh $83,57 \%$ termasuk kualifikasi sangat baik dengan keterangan tidak revisi/valid. Dapat disimpulkan bahwa media pembelajaran ini layak untuk di gunakan pada proses pembelajaran.
\end{abstract}

Kata Kunci: Bio Pop-Up Book; SETS; Biogeokimia

\begin{abstract}
:
This research aims to develop SETS integrated Bio Pop-Up Book learning media on Biogeochemical cycle materials. This is because in this material a real media is needed so that students can imagine it. So that in the learning process students can bring up the intellectual ability to solve a problem. In harmony with science, environment, technology, and society. This research is a research development. The development research method used is ADDIE which consists of five stages which include analysis, design, development, implementation, and evaluation. Data obtained by validation of material experts and learning media experts. The results of the material expert validation were obtained $87 \%$ including very good qualifications and learning media expert validation results obtained by $83.57 \%$ including very good qualifications with non revised/ valid information. It can be concluded that this learning media is feasible to be used in the learning process.
\end{abstract}

Keywords: Bio Pop-Up Boo; SETS; Biogeochemical Cycle

\section{Pendahuluan}

Pendidikan merupakan persoalan penting bagi bangsa Indonesia, karena dapat mempengaruhi kemajuan dari suatu negara. Oleh karena itu peningkatan kualitas pendidik menjadi hal penting untuk diperhatikan. Proses pembelajaran dengan penggunaan media pembelajaran bertujuan untuk mempermudah penyampaian materi pembelajaran pada peserta

Wahyu Dwi Lestari, Universitas PGRI Madiun

wahyudwio9091997@gmail.com

Wachidatul Linda Yuhanna, Universitas PGRI Madiun

linda.yuhanna@unipma.ac.id

Marheny Lukitasari, Universitas PGRI Madiun

marheny@unipma.ac.id 
didik, termasuk dalam pembelajaran biologi. Penyampaian materi yang sistematis dan bermakna tidak terlepas dari peran penggunaan modul, bahan ajar dan media yang menarik (Ambinari et al., 2019). Penggunaan bahan ajar dan media pembelajaran diharapkan membantu peserta didik dalam belajar (T. Megadani, M. Lukitasari, 2018). Pengembangan pembelajaran biologi membutuhkan pendekatan yang mampu meningkatkan prestasi peserta didik (Yuhanna et al., 2017). Pendekatan yang akan digunakan adalah pendekatan Science, Environment, Technology, And Society SETS, yaitu pendekatan pembelajaran terpadu yang melibatkan empat unsur yaitu sains, lingkungan, teknologi dan masyarakat.

SETS adalah pendekatan pembelajaran yang membawa peserta didik agar memiliki kemampuan memandang sesuatu secara terintegratif dengan mengkaitkan keempat unsur SETS. Pengajaran SETS fokus pada bagaimana peserta didik dapat melakukan penyelidikan untuk mendapatkan pengetahuan sains, lingkungan, teknologi dan masyarakat yang saling berkaitan. Dengan demikian metode ini memberi kesempatan peserta didik untuk mengembangkan lebih jauh pengetahuan yang diperoleh dalam menyelesaikan masalah disekitar kehidupannya (Permatasari dkk., 2019). Menurut Yörük (2010) STSE berasal dari keyakinan bahwa koneksi antara siswa dan dunia nyata harus dibangun. Proses ini akan membuat siswa mengenali kemungkinan masalah yang dia miliki. Lingkungan diciptakan, di mana siswa dapat mengumpulkan data untuk solusi dari masalah mereka, mempertimbangkan cara solusi alternatif, menentukan cara terbaik untuk memecahkan masalah dan mempraktikkannya.

Penggunaan media pembelajaran 3D dapat dijadikan alternatif pembelajaran salah satunnya seperti Pop-Up Book. Novianti (2019) berpendapat bahwa media pembelajaran akan mempermudah dalam pelaksanaan proses pembelajaran. Media pembelajaran sangat penting dalam membantu proses pembeljaran menjadi efektif dan efisien. Nikmah (2019) menguatkan bahwa media pembelajaran memiliki kegunaan untuk mengatasi keterbatasan ruang waktu dan daya indera. Hal ini disebabkan karena penggunaan media yang sesuai dapat meminimalisir penggunaan waktu dalam menyampaikan materi. Pengunaan media yang menarik dapat di gunakan dalam pembelajaran biologi. Selain itu media pembelajaran akan menarik perhatian peserta didik. Sesuai dengan media yang dikembangkan dalam pembelajaran biologi adalah Bio Pop-Up Book.

Media Bio Pop-Up Book merupakan media pembelajaran berbentuk 3 dimensi yang mampu menggambarkan objek secara utuh sehingga peserta didik lebih mudah dalam memahami suatu materi. Kelebihan penggunaan media pembelajaran Bio Pop-Up Book karena unik dan menarik serta mampu memunculkan kreatifitas peserta didik. Penggunaan media Pop-Up Book dalam pembelajaran biologi menjadikan peserta didik lebih aktif dan kreatif dalam proses pembelajaran. Media pembelajaran ini dapat digunakan dalam kelas skala besar. Pelaksanaan pembelajaran biologi selama ini hanya dilaksanakan dengan metode ceramah.

Penggunaan media pembelajaran Bio Pop-Up Book yang di terapkan ini berbeda dengan pengembangan yang sudah dilakukan sebelumnya. Pengembangan media Pop-Up Book yang digunakan sehingga memiliki perbedaan dengan pengembangan yang lainya yaitu karena pengembangan ini terintegrasi SETS. Dimana 4 unsur dalam pendekatan ini saling berkaitan satu dengan yang lainnya. Umami (2013) berpendapat bahwa dalam proses pembelajaran yang menerapkan pendekatan SETS dilakukan peserta didik dengan mengajak untuk menemukan dan menyelidiki. Hasil penelitian Harahap, dkk., (2016) menunjukkan bahwa pendekatan SETS efektif di gunakan meningkatkan prestasi akademik dan pengetahuan peserta didik dalam menyerap materi. Dalam hal ini guru yang berperan sebagai fasilitator, motivator, dan pengajar, perlu menekankan agar peserta didik melibatkan diri saat diskusi dengan guru dan sesama 
peserta didik. Kemudian melibatkan peserta didik dalam situasi yang sebenarnya pada proses pembelajaran sehingga membentuk keyakinan dan sikap peserta didik (Binadja, 2012). Tujuan dari penelitian ini adalah mengembangkan media pembelajaran Bio Pop-Up Book terintegrasi SETS pada materi daur Biogeokimia dan mengetahui kelayakannya dari aspek media dan materi berdasarkan penialian, saran dan masukan dari validator.

\section{Metode}

Penelitian ini merupakan penelitian pengembangan. Metode penelitian pengembangan yang digunakan adalah ADDIE yang terdiri dari lima tahapan yang meliputi analisis (Analysis), desain (design), pengembangan (development), implementasi (implementation), dan evaluasi (evaluation). Hadi (2016) berpendapat bahwa model ADDIE merupakan model yang sederhana dalam prosesnya, akan tetapi implementasinya sistematis. Puspasari ( 2019) mengatakan bahwa model ADDIE sering digunakan untuk berbagai macam bentuk pengembangan produk, seperti staregi pembelajaran,model pembelajaran, medi dan bahan ajar. Pengembangan Produk yang dilakukan dalam penelitian ini adalah pembuatan media pembelajaran Bio Pop-Up Book terintegrasi SETS pada materi daur biogeokimia. Rancangan penelitian ini mengadaptasi model pengembangan ADDIE, yaitu model pengembangan yang terdiri dari lima tahapan yang meliputi analisis (Analysis), desain (Design), pengembangan (Development), implementasi (Implementation), dan evaluasi (Evaluation). Berikut merupakan skema tahapan-tahapan dari penelitian menggunakan mode ADDIE.

Penelitian ini dilaksanakan di lingkungan kelas Program Studi Pendidikan Biologi kampus 1 lantai 2 Universitas PGRI Madiun yang beralamatkan Jalan Setia Budi No. 85 Madiun Provinsi Jawa Timur. Penelitian ini akan dilaksanakan selama empat (4) bulan. Teknik pengumpulan data adalah cara peneliti memperoleh data dalam penelitiannya. Data di tahap ini merupakan data kelayakan produk. Kelayakan produk dinilai dari lembar validasi yang terdiri dari validasi materi, dan validasi media pembelajaran dengan melakukan penyebaran angket validasi.

Tabel 1. Instrumen validasi materi (Rahmawati dkk., 2020).

\begin{tabular}{|c|c|c|c|c|c|c|}
\hline No. & Butir Penilaian & SB & B & CB & KB & TB \\
\hline 1. & Kesesuaian isi materi dengan kompetensi inti & & & & & \\
\hline 2. & Kesesuaian isi materi dengan kompetensi dasar & & & & & \\
\hline 3. & $\begin{array}{l}\text { Kesesuaian isi materi dengan indikator dan tujuan } \\
\text { pembelajaran }\end{array}$ & & & & & \\
\hline 4. & Kelengkapan materi daur biogeokimia & & & & & \\
\hline 5. & Kebenaran konsep materi daur biogeokimia & & & & & \\
\hline 6. & Ketepatan cakupan materi daur biogeokimia & & & & & \\
\hline 7. & Keluasan materi materi daur biogeokimia & & & & & \\
\hline 8. & Kesesuaian gambar untuk memperjelas materi & & & & & \\
\hline 9. & Kemenarikan penyajian materi & & & & & \\
\hline
\end{tabular}

Tabel 2. Kriteria penilaian pengembangan media pembelajaran

\begin{tabular}{cl}
\hline Skor & Indikator \\
\hline 5 & Sangat baik \\
4 & Baik \\
3 & Cukup Baik \\
2 & Kurang baik \\
1 & Tidak baik \\
\hline
\end{tabular}

Tabel 3. Instrumen validasi media 


\begin{tabular}{|c|c|c|c|c|c|c|}
\hline No & Butir Penilaian & SB & B & CB & KB & TB \\
\hline 1. & $\begin{array}{l}\text { Penampilan unsur tata letak cover depan dan } \\
\text { cover belakang }\end{array}$ & & & & & \\
\hline 2. & $\begin{array}{l}\text { Penyajian media secara keseluruhan dapat } \\
\text { mempresentasi konsep/materi siklus } \\
\text { biogeokimia }\end{array}$ & & & & & \\
\hline 3. & Kesesuaian kerapian tata letak gambar & & & & & \\
\hline & $\begin{array}{l}\text { Kesesuaian gambar yang di gunakan terlihat } \\
\text { nyata dan menarik }\end{array}$ & & & & & \\
\hline & Tampilan umum mediamenarik & & & & & \\
\hline & $\begin{array}{l}\text { Media bisa digunakan diberbagai tempat, } \\
\text { waktu, dan keadaan }\end{array}$ & & & & & \\
\hline & $\begin{array}{l}\text { Media yang digunakan bersifat menyenangkan } \\
\text { dan efektif dalam penggunaanva }\end{array}$ & & & & & \\
\hline & $\begin{array}{l}\text { Media Pop-Up Book mudah di gunakan oleh guru } \\
\text { dan peserta didik }\end{array}$ & & & & & \\
\hline & $\begin{array}{l}\text { Kemampuan media dalam membantu peserta } \\
\text { didik memahami konsep/materi siklus } \\
\text { biogeokimia }\end{array}$ & & & & & \\
\hline & $\begin{array}{l}\text { Media Pop-Up Book tidak membahayakan } \\
\text { peserta didik }\end{array}$ & & & & & \\
\hline & $\begin{array}{l}\text { Media Pop-Up Book dapat tahan lama dan dapat } \\
\text { diguankan berulang-ulang }\end{array}$ & & & & & \\
\hline & Media Pop-Up Book terlihat kreatif dan inovatif & & & & & \\
\hline & $\begin{array}{l}\text { Media Pop-Up Book dapat memberikan ilustrasi } \\
\text { yang sesuai dengan keadaan sebenarnya }\end{array}$ & & & & & \\
\hline & $\begin{array}{l}\text { Ukuran media Pop-Up Book yang di gunakan } \\
\text { proposional }\end{array}$ & & & & & \\
\hline
\end{tabular}

Tabel 4. Kriteria penilaian pengembangan media pembelajaran

\begin{tabular}{cl}
\hline Skor & Indikator \\
\hline 5 & Sangat baik \\
4 & Baik \\
3 & Cukup Baik \\
2 & Kurang baik \\
1 & Tidak baik \\
\hline
\end{tabular}

Sumber: (Rahmawati dkk., 2020)

Adapun analisis lembar validasi yang diperoleh berdasarkan tanggapan para ahli validator ditentukan dengan rumus :

$\mathrm{P}=\frac{\sum \text { (seluruh skor jawaban angket }}{n \times \text { terting } \mathrm{xi} \text { jumlah responden }} \times 100 \%$

Keterangan: 
$\mathrm{P}=$ menyatakan presentase penilaian

$\mathrm{n}=$ menyatakan jumlah seluruh item angket

Sumber :(Zunaidah \& Amin, 2016)

Hasil akhir dari perhitungan rumus nilai validasi disesuaikan dengan kriteria kelayakan produk. Adapun kriteria validasi yang digunakan dalam penelitian sebagaimana tabel 5.

Tabel 5. Kriteria validasi

\begin{tabular}{lll}
\hline $\begin{array}{c}\text { Tingkat } \\
\text { pencapaian } \%\end{array}$ & \multicolumn{1}{c}{ Kualifikasi } & \multicolumn{1}{c}{ Keterangan } \\
\hline $81-100 \%$ & Sangat baik & Valid / dapat digunakan tanpa revisi \\
\hline $61-80 \%$ & Baik & Valid / dapat digunkan dengan direvisi \\
\hline $41-60 \%$ & Cukup & Kurang valid / disarankan tidak digunakan perlu evisi \\
\hline $21-40 \%$ & Kurang & Tidak valid / tidak boleh digunakan perlu revisi besar-besaran \\
\hline$<20 \%$ & Sangat kurang & Sangat tidak valid / tidak boleh digunakan \\
\hline
\end{tabular}

Sumber: (Rahmawati dkk., 2020)

\section{Hasil dan Pembahasan}

Penelitian pengembangan yang dilakukan bertujuan menghasilkan media pembelajaran Bio Pop-Up Book yang nantinya akan digunakan dalam pembelajaran biologi pada materi Daur Biogeokimia. Bio Pop-Up Book ini nantinya akan digunakan peserta didik sebagai alternatif media pada proses pembelajaran. Jenis penelitian yang digunakan ialah penelitian pengembangan Reseach and Development (R\&D) model ADDIE dengan tahapan analisis (Analysis), desain (Design), pengembangan (Development), implementasi (Implementation), dan evaluasi (Evaluation).

\section{a. Analisis (Analysis)}

Tahap analisis dilakukan untuk menentukan suatu produk yang akan dikembangkan. Hasil analisis kurikulum menghasilkan bahwa materi Daur Biogeokimia diterapkan dikelas X pada mata pelajaran Biologi dengan Standar Kompetensi sebagaimana tabel 6. Implementasi kurikulum 2013 ini memasukkan penguatan sikap spiritual, sikap sosial, pengetahuan dan keterampilan dalam proses pembelajaran. Proses pembelajaran ialah kunci utama dalam kegiatan pembelajaran peserta didik. Prinsip dari kurikulum k13 berpusat pada peserta didik mengembangkan kreativitas peserta didik.

Tabel 6. Kompetensi inti dan kompetensi dasar kelas $X$

\begin{tabular}{ll}
\hline \multicolumn{1}{c}{ Kode } & \multicolumn{1}{c}{ Kompetensi } \\
\hline Kompetensi inti & Menghayati dan mengamalkan ajaran agama yang dianutnya \\
\hline KI 1: & Mengamati dan mengamalkan perilaku jujur, disiplin, tanggung jawab, peduli \\
& (gotong royong, kerjasama, toleran, damai), santun, responsive, proaktif dan \\
& menunjukkan sikap sebagai bagian dari solusi atas berbagai permasalahan dalam \\
& berinteraksi secara efektif dengan lingkungan social dan alam serta dalam \\
& menempatkan diri sebagai cerminan bangsa dalam pergaulan dunia. \\
\hline KI 3: & Memahami, menerapkan, menganalisis pengetahuan faktual, konseptual, \\
& prosedural berdasarkan rasa ingintahunya tentang ilmu pengetahuan, teknologi, \\
& seni, budaya, dan humaniora dengan wawasan kemanusiaan, kebangsaan, \\
& kenegaraan, dan peradaban terkait penyebab fenomena dan kejadian, serta \\
\hline
\end{tabular}




\begin{tabular}{ll}
\hline & $\begin{array}{l}\text { menerapkan pengetahuan prosedural pada bidang kajian yang spesifik sesuai } \\
\text { dengan bakat dan minatnya untuk memecahkan masalah }\end{array}$ \\
\hline KI 4: & $\begin{array}{l}\text { Mengolah, menalar, dan menyaji dalam ranah konkret dan ranah abstrak terkait } \\
\text { dengan pengembangan dari yang dipelajarinya di sekolah secara mandiri dan } \\
\text { mampu menggunakan metoda sesuai kaidah keilmuan }\end{array}$ \\
\hline Kompetensi dasar \\
\hline 3.9 & $\begin{array}{l}\text { Menganalisis komponen-komponen ekosistem dan interaksi antar komponen } \\
\text { tersebut }\end{array}$ \\
\hline 4.9 & $\begin{array}{l}\text { Menyajikan karya yang menunjukkan interaksi antar komponen ekosistem } \\
\text { (jaringjaring makanan, siklus Biogeokimia) }\end{array}$ \\
\hline
\end{tabular}

Hasil analisis materi digunakan untuk mengidentifikasi, merinci, dan menyusun konsep secara sistematis dan relevan yang akan dimasukkan pada pengembangan Bio Pop-Up Book. Materi yang dipilih dalam pengembangan ini adalah materi Daur Biogeokimia, karena bersifat abstrak menunjukkan suatu fenomena alam yang cenderung sulit dilihat secara nyata oleh mata, sehingga membutuhkan media untuk membayangkan fenomena tersebut. Terdapat 6 materi yang ter muat dari Daur Biogeokimia ini yaitu siklus nitrogen, siklus karbon, siklus oksigen, siklus air, siklus fosfor, dan siklus sulfur.

b. Perancangan (Design)

Hasil tahap design yaitu merancang kerangka Bio Pop-Up Book yang dilengkapi dengan informasi mengenai siklus Daur Biogeokimia. Perancangan meliputi kegiatan penyusunan materi, pengumpulan gambar, dan juga desain dari Pop-Up Book ini. Materi Daur Biogeokimia adalah 6 siklus yaitu Siklus nitrogen, Siklus karbon, Siklus oksigen, Siklus air, Siklus fosfor, dan Siklus sulfur. Gambar penunjang isi dari Bio Pop-Up Book yang merupakan kekuatan dari media ini didapatkan dari internet. Desain Pop-Up Book yang terintegrasi SETS sebagaimana gambar 1 .

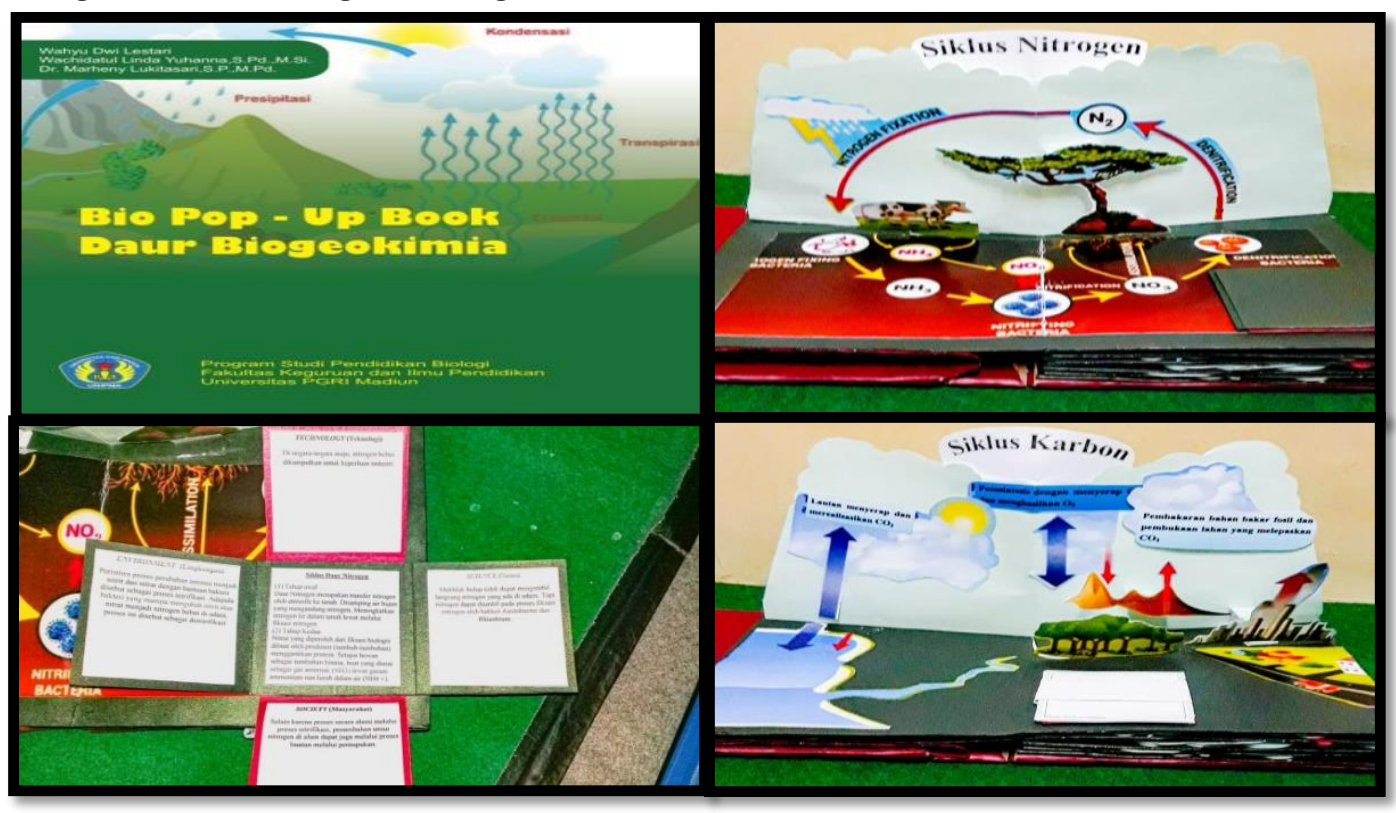

Gambar 1. Desain bio pop up book daur biogeokimia 


\section{c. Pengembangan (Development)}

Tahap pengembangan merupakan desain awal berdasarkan hasil perancangan. Tahap ini ialah hasil perencanaan awal Pop-Up Book dan instrumen, hasil validasi ahli, dan revisi yang nantinya akan dikembangkan menjadi suatu Pop-Up Book yaitu Bio Pop-Up Book yang terintegrasi SETS. Berikut adalah proses pengembangan Bio Pop-Up Book yang terintegrasi SETS terdiri dari :

1. Desain Bio Pop-Up Book

Pengembangan Pop-Up Book dilaksanakan sesuai dengan desain yang telah dibuat. Cover Pop-Up Book cover dibuat dengan menggunakan aplikasi corel yang ukuran akan disesuaikan dengan ukuran layout $21 \mathrm{~cm}$ x 25,7 cm. Materi siklus Daur Biogeokimia yang telah disusun menjadi Pop-Up Book yang terintegrasi SETS. Isi media Pop-Up Book disusun penuh dengan muatan SETS.

2. Validasi produk Bio Pop-Up Book

Pada tahap ini dilakukan beberapa hal yaitu validasi instrumen penelitian berupa validasi ahli materi dan ahli media. Validasi ini memiliki tujuan untuk meminta pertimbangan ahli berupa komentar dan saran mengenai kekurangan produk yang telah dibuat. Validasi materi Bio Pop-Up Book yang terintegrasi SETS menggunakan instrumen yang telah disiapkan. Hasil dari validasi materi Bio Pop-Up Book yang terintegrasi SETS menunjukkan nilai $87 \%$ sehingga materi tersebut sangat baik untuk digunakan. Berdasarkan hasil penilaian validator ahli materi kedua validator yaitu sebesar $85 \%$, sehingga penilaian materi pada Bio Pop-Up Book yang terintegrasi SETS termasuk pada kualifikasi "sangat baik" dengan keterangan valid.

Validasi ahli media Bio Pop-Up Book yang terintegrasi SETS menggunakan menggunakan instrumen yang telah disusun. Hasil dari validasi media Bio Pop-Up Book yang terintegrasi SETS di peroleh nilai $83,57 \%$ yang menyatakan bahwa media ini layak untuk digunakan. Hasil perhitungan dari kedua validator menunjukkan bahwa media pada Bio Pop-Up Book yang terintegrasi SETS termasuk pada kualifikasi "sangat baik" dengan keterangan valid / dapat digunakan tanpa revisi

\section{d. Implementasi (Implementation)}

Pada tahap ini setelah media pembelajaran Bio Pop-Up Book yang terintegrasi SETS sudah mendapatkan validasi dari ahli materi dan media serta sudah melaksanakan revisi sesuai dengan komentar dan saran. Hasil dinyatakan layak selanjutnya dilakukan diimplementasikan skala kecil pada 30 orang siswa. Hasil menunjukkan bahwa $92 \%$ siswa antusias, tertarik dan setuju dengan penggunaan Bio Pop-Up Book. Implementasi skala besar dilakukan di kelas belum bisa dilaksanakan di tengah Pandemi Covid19.

\section{e. Evaluasi (Evaluation)}

Evaluasi dilakukan pada seluruh tahap pengembangan yang telah dilakukan sebelumnya. Evaluasi ini dilaksanakan denagn cara menyempurnakan produk yang telah di buat. Berdasarkan saran dan masukan para ahli yang meliputi kekurangan dan kelebihan. Evaluasi dari ahli materi yaitu untuk lebih memper luas materi dantelah di revisi dengan menambahkan materi yang kurang. Evaluasi dari ahli media memberikan judul pada tiap-tiap siklus dan perbaikan cover telah direvisi dengan memberikan judul pada tiap-tiap siklis dan cover telah di perbaiki. 
Media pembelajaran mata pelajaran biologi pada materi siklus biogeokimia yang dikembangkan adalah Pop Up Book dalam bentuk cetak. Hal tersebut sesuai dengan pendapat Handaruni (2018) bahwa media pembelajaran meliputi alat yang secara fisik digunakan untuk menyampaikan isi materi pembelajaran, yang terdiri dari anatara lain buku, tape recorder, kaset, video camera, video recorder, film, slide (gambar bingkai), foto, gambar grafik, televisi dan computer. Media dalam bentuk cetak ini disarankan untuk melatih minat membaca yang disajikan secara visual. Media Pop Up Book sendiri merupakan media pembelajaran yang berbentuk buku 3 dimensi. Hal ini di benarkan oleh (Baiduri, dkk 2019), yang menyatakan bahwa Pop-Up Book merupakan media pembelajaran berbentuk 3 dimensi, dengan materi yang akan disajikan dengan gambar. Pop-Up Book berbahan utama kertas yang disusun membentuk suatu siklus sehingga menyajikan gambar yang menarik, dan dapat membuat pesrta didik lebih semangat dalam proses pembelajaran.

Pengembangan yang dilakukan pada media ini adalah dengan menggunakan pendekatan SETS yang ada sehingga peserta didik akan memiliki kreatifitas yang tinggi dalam proses pembelajaran. Hal tersebut sesuai dengan pendapat yang dikemukakan oleh Kusjuriansah (2019) menyatakan bahwa pendekatan SETS menambah nilai positif jika diintegrasikan dengan nilai-nilai agama sehingga perkembangan aspak kognitif, efektif, psikomotorik peserta didik menjadi lebih positif. Hal ini sesuai dengan pendapat Fitri (2019) yang menyebutkan bahwa efek positif dari SETS adalah dapat meningkatkan keterampilan berpikir kritis siswa dan mereka akan kreatif dalam membuat keputusan terkait dengan sains dan konteks kehidupan sehari-hari.

Analisis awal diperoleh hasil menganalisis kompetensi inti serta kompetensi dasar berdasarkan silabus yang telah disusun menurut kurukulum 2013. Menurut kemendikbud 2013 (dalam Setyadi dkk, 2017) kurikulum 2013 adalah kurikulum baru yang baru diterapkan pada tahu ajaran 2013/2014 yang bertujuan melatih ketrampilan proses yang dicerminkan dalam kegiatan pembelajaran. Ketrampilan proses ini meliputi 5M yaitu, mengamati, menanya, mengumpulkan data, mengasosiasikan, dan mengkomunikasikan. Salah satunya tahap analisis yaitu analisis KI dan KD mendapatkan media pembelajaran yang sesuai yaitu Bio Pop-Up Book yang terintegrasi SETS. Sedangkan untuk tahapan analisis materi digunakan untuk mengidentifikasi, merinci, dan menyusun konsep secara sistematis dan relevan yang akan dimasukkan pada pengembangan Bio Pop-Up Book.

Materi yang dipilih dalam pengembangan ini adalah materi Daur Biogeokimia. Materi Daur Biogeokimia dipilih karena bersifat abstrak menunjukkan suatu fenomena alam yang sulit dilihat secara nyata oleh mata, sehingga membutuhkan media untuk membayangkan fenomena tersebut. Sehingga membutuhkan media pembelajaran yang sesuai, seperti contohnya media pembelajaran Bio Pop-Up Book. Hal ini sesuai dengan pendapat dari Dewalitfi, (2017) yang menyatakan bahwa materi daur bigeokimia ini memiliki karakteristik materi daur biogeokimia yaitu bersifat abstrak, serta sulit disimulasikan di kelas secara nyata karena dibutuhkan waktu sangat lama dalam prosesnya.

\section{SIMPULAN}

Berdasarkan pengembangan yang telah di lakukan dapat disimpulkan bahwa media pembelajaran Bio Pop-Up Book terintegrasi SETS pada materi Daur Biogeokimia. sesuai dengan KI dan KD yang ada. Hasil dari validasi ahli media dan juga ahli materi menunjukkan angka 
presentase kelayakan media sebesar $83,57 \%$ maka dapat menunjukan proses pembelajaran akan lebih menarik. Presentase kelayakan materi menunjukan angka kelayakan sebesar $87 \%$ yang berarti baik dan tidak perlu adanya perbaikan. Hasil menunjukkan bahwa $92 \%$ siswa antusias, tertarik dan setuju dengan penggunaan Bio Pop-Up Book. Implementasi skala besar dilakukan di kelas belum bisa dilaksanakan di tengah Pandemi Covid19.

\section{Daftar Rujukan}

Ambinari, M., Yuhanna, W. L., \& ... (2019). Penyusunan Modul Anatomi Dan Histologi Hewan Berbasis Hasil Penelitian. Prosiding Seminar ..., September, 29-35. http://prosiding.unipma.ac.id/index.php/simbiosis/article/view/635

Baiduri, B. B., Taufik, M.-, \& Elfiani, L.-. (2019). Pengembangan Media Pembelajaran Pop-Up Book Berbasis Audio Pada Materi Bangun Datar Segiempat Di Smp. AKSIOMA: Jurnal Program Studi Pendidikan Matematika, 8(1), 248-261. https://doi.org/10.24127/ajpm.v8i1.1951

Hadi, H., \& Agustina, S. (2016). Pengembangan Buku Ajar Geografi Desa-Kota Menggunakan Model Addie. Jurnal Educatio, 11(1), 90-105.

Handaruni Dewanti, Anselmus J E Toenlioe, Y. S. (2018). Pengembangan media Pop-Up Book untuk Pembelajaran Lingkungan Tempat Tinggalku Kelas IV SDN 1 Pakuaden Kabupaten Ponorogo. Jurnal Kajian Teknologi Pendidikan, 1(3), 221-228.

Harahap, Y., Indriyanti, dyah rini, \& Mariyanti, A. (2016). Journal of Biology \& Biology Education. Keefektifan Media Pembelajaran "Si Imut" Berbasis Masalah Materi Sistem Imun Terhadap Sikap Peka Dan Peduli Keselamatan Diri Dan Lingkungan Siswa, 5(24), 3-4.

Kusjuriansah, \& Yulianto.Agus. (2019). Unnes Physics Education Journal Pengembangan Bahan Ajar Fisika Berbasis I-SETS Terkomplementasi Karakter Pada. 8(2).

Nikmah, S., Nuroso, H., \& Reffiane, F. (2019). Pengaruh Model Pembelajaran Terpadu Tipe Shared Berbantu Media Pop- Up Book Terhadap Hasil Belajar. Jurnal Pedagogi Dan Pembelajaran, 2(2), 264. https:// doi.org/10.23887/jp2.v2i2.17920

Novianti, N., Nugroho, E. D., \& Ilma, S. (2019). Pengembangan media pembelajaran pop-upsnakes and ladders pada materi archaebacteria dan eubacteria kelas $x$ sma/ma di daerah perbatasan. 1(1), 34-45.

P., S., Binadja, A., \& -, S. (2012). Pengembangan Perangkat Pembelajaran Kimia Kelarutan Dan Hasil Kali Kelarutan (Ksp) Dengan Pendekatan Sets Untuk Meningkatkan Kreativitas Dan Hasil Belajar Peserta Didik. Journal of Educational Research and Evaluation, 1(1), 149-158.

Permatasari, I., Ramdani, A., \& Syukur, A. (2019). Pengembangan Bahan Ajar IPA Berbasis Inkuiri Terintegrasi Sets (Science, Environment, Technology And Society) pada Materi Sistem Reproduksi Manusia. Jurnal Pijar Mipa, 14(2), 74-78. https:/ / doi.org/10.29303/jpm.v14i2.1256

Puspasari, R. (2019). Pengembangan Buku Ajar Kompilasi Teori Graf dengan Model Addie. Journal of Medives: Journal of Mathematics Education IKIP Veteran Semarang. https://doi.org/10.31331/medivesveteran.v3i1.702 
Rahmawati, A., Ermawati, I. R., \& Laksanawati, W. D. (2020). Pengembangan Media Pembelajaran Fotonovela Berbasis Nilai Karakter Untuk Anak Tunarungu Smalb Pada Materi Magnet. WaPFi (Wahana Pendidikan Fisika), 5(1), 56-60.

T. Megadani, M. Lukitasari, W. Y. (2018). Pengembangan modul biologi pada materi pertumbuhan dan perkembangan berbasis metakognisi. Prosiding Seminar Nasional SIMBIOSIS III, September, 302-311.

Umami, R., \& J. (2013). Penerapan Model Pembelajaran Inkuiri dengan Pendekatan SETS (Science, Environment, Technology, Society) Pada Pokok Bahasan Fluida Statis untuk Meningkatkan Keterampilan Berpikir Kritis Siswa Kelas XI SMA Negeri 1 Gedangan. Jurnal Inovasi Pendidikan Fisika, 2(03), 2013.

Yörük, N., Morgil, I., \& Seçken, N. (2010). The effects of science, technology, society, environment (STSE) interactions on teaching chemistry. Natural Science, 02(12), 1417-1424. https://doi.org/10.4236/ns.2010.212173

Yuhanna, W. L., Retno, R. S., \& Juwanita, J. (2017). Implementasi Pembelajaran “Inquiry Small Research" Untuk Meningkatkan Sikap Ilmiah Dan Prestasi Belajar Mahasiswa Pendidikan Biologi. Bioilmi: Jurnal Pendidikan, 3(2), 71-77. https://doi.org/10.19109/bioilmi.v3i2.1397

Zunaidah, F. N., \& Amin, M. (2016). Developing the Learning Materials of Biotechnology Subject Based on Students' Need and Character of Nusantara Pgri University of Kediri. Jurnal Pendidikan Biologi Indonesia, 2(1), 19-30. https:// doi.org/10.22219/jpbi.v2i1.3368 